\title{
Migration and the historical formation of Latin America in a global perspective
}

\section{José C. Moya*}

\begin{abstract}
In this article I analyse how transcontinental migrations, the various forms that these took (Paleolithic first settlement, conquest and colonialism, slavery, free mass movements, and mercantile diasporas), and the way these interacted in the receiving environments, shaped the historical formation of Latin America. The article shows how these interactions explain the key apparent contradictions of Latin America: that it is both the most racially diverse and the most culturally homogeneous region in the world; that it has the highest crime/homicide rates but also the lowest levels of civil and international wars, holocausts, and other forms of collective violence; and that it has the highest levels of social inequality in the world but also some of its historically most egalitarian areas.
\end{abstract}

Keywords: Migration, Slavery, Latin America, Race and ethnicity, Atlantic World.

* Columbia University, New York, NY, United States of America. 


\section{La migración y la formación histórica de América Latina en una perspectiva global}

\section{Resumen}

En este artículo analizo cómo las migraciones transcontinentales, en las diversas formas que asumieron (el primer asentamiento paleolítico, conquista y colonialismo, esclavitud, movimientos de masa libres y diásporas mercantiles) y la manera como éstas interactuaron con los entornos receptores ha determinado la formación histórica de América Latina. El artículo muestra cómo estas interacciones explican las aparentes contradicciones de América Latina: el hecho de ser la región más diversa del mundo en términos raciales y, al mismo tiempo, aquella culturalmente más homogénea; la que exhibe las tasas más altas de criminalidad / homicidio, pero también los menores índices de guerras civiles e internacionales, holocaustos y otras formas de violencia colectiva; y la que muestra los más altos índices mundiales de desigualdad social, pero que incluye también algunas de las áreas históricamente más igualitarias en el mundo.

Palabras clave: Migración, Esclavitud, América Latina, Raza y Etnia, Mundo atlántico.

\section{M}

igration is a universal and, at some level, a trans-historical phenomenon. It is, after all, one of the four mechanisms of biological evolution (along with mutations, genetic drift, and natural selection) and thus part of the emergence of our species and most others. In this sense, it both precedes and creates human history. It is also how we spread globally from our southeastern African cradle, the source of racial and cultural diversity, and how we have responded to ecological challenges other than adaptation in situ, which is a relatively recent phenomenon in our long history.

Yet transcontinental migration has played an exceptionally important role in the Americas. No other continent (and in Latin America the Western Hemisphere is conceived as one continent rather than two, as it is in AngloAmerica) was formed entirely by immigrants from every other continent. 
Even its aboriginal inhabitants arrived not as Homo sapiens coming out of Africa but as northeastern Asian immigrants both phenotypically and culturally, long after most of the rest of the world had been populated. Over two-thirds of Latin America's population descend from people who arrived after 1492. If one excludes the central Andes (Bolivia, Peru, and Ecuador) and Mesoamerica (Honduras, Guatemala, and the southernmost quarter of Mexico), that figure goes up to $78 \% .^{1}$ In no other place outside of the Americas, Australia, and New Zealand is the population so new. In Africa, Asia, and Europe, over $94 \%$ of the population trace their origins to people who had been there for thousands of years.

In this article I consider how transcontinental migrations shaped the historical formation of Latin America over the longue durée. The article starts with a discussion of pre-Columbian and colonial migrations because they molded the environment into which later postcolonial immigrants would be inserted. Then, I examine the mass arrivals from Africa up to the middle of the nineteenth century and from Europe over the last two centuries, and how these movements reshaped Latin America.

\section{Pre-Columbian migrations and the gap in connectivity}

Humans first arrived in the Americas from northeast Asia about 15,000 years ago, or between 30,000 and 70,000 years later than to other continents. Their late arrival accounts for many of the demographic traits of the Amerindian population Europeans would encounter after 1492. Because they had had tens of thousands fewer years in which to reproduce, the population was significantly smaller both in absolute and per area terms than elsewhere. The number of people per square kilometer was three times lower than in Africa, six times lower than in

1 The figures for continental origins of the population of Latin American countries were calculated from data culled by Putterman and Weil (2010). For the racial composition in Mexican states I used data on indigenous language use collected by the Instituto Nacional de Estadísticas y Geografía and genomic data in Silva-Zolezz, et al. (2009). 
Asia, and eight times lower than in Europe. ${ }^{2}$ The population was both less dense and less spread than in Eurasia and Africa, with over twothirds concentrating in nuclear America (Mesoamerica and the central Andes), an area that occupies only 9\% of the hemisphere. The lower density and diffusion of the population combined with geographical traits to inhibit internal mobility and connectivity. The elongated shape of the Western Hemisphere along a north-south axis (compared to the east-west axis of Eurasia) generates greater climatic change and hindered the diffusion of domesticated plants and animals. The mountain ranges that run along the western side of the Americas from Alaska to Chile, the deserts that run from Nevada to Chihuahua and from Atacama to Patagonia, the Darien jungle on the Isthmus of Panama, and parts of Amazonia added impediments to the movement of people and their material culture (Moya, 2017).

The contrast in the level of connectivity and diffusion between the New and Old World is striking. Potatoes, quinoa, Ilamas, guinea pigs, bronze, rope bridges, and the quipu (a counting technique) were domesticated or developed in the central Andes but did not spread to Mesoamerica or anywhere else in pre-Columbian America. Similarly, tomatoes, turkeys, writing, and the concept of zero were domesticated or developed in Mesoamerica and stayed there. On the other hand, wheat, barley, lentils, flax, cattle, horses, sheep, goats, cats, the honey bee, bronze, iron, the alphabet, and Arabic numerals were domesticated or developed in the Middle East and spread throughout Eurasia. Indeed, of all the technological and material advantages that explain why Spaniards were able to reach and conquer Amerindians and not the other way around (caravels that could sail against the wind, the compass, astrolabe, cartography, printing, steel, firearms, horses and other domesticated animals, and immunity to smallpox) not a single one had been domesticated or developed in Spain (Moya, 2014).

\footnotetext{
${ }^{2}$ Calculated from data in Caselli, Vallin, and Wunsch (2006).
} 
The wider gaps in technological development within the New World, where bronze-age cultures in nuclear America abutted Paleolithic groups, and between the Americas and Eurasia resulted from these gaps in the level of mobility, contacts and connectivity. There was limited or no contact between South and North America, between the two sites of complex culture in nuclear America, between these sites and the rest of the hemisphere, and between the Americas and the rest of the world - including, with terrible consequences after 1492, its disease environment.

The low population density outside of nuclear America, the decimation of the Amerindian population in the decades after the conquest, and the military and technological advantages of the conquerors help explain another distinctive characteristic of Latin America: the deep impact that the post 1492 colonizers would have in comparison to others elsewhere.

\section{Iberian Migration and Colonization in Comparative Perspective}

The transformative capacity of Iberian colonialism in the Americas reflected not only the distinctive characteristics of the New World but also of Iberian colonial migration to it. The wealth and opportunities generated by silver in the viceroyalties of New Spain and Peru and by a gold and diamond boom in eighteenth-century Brazil attracted hundreds of thousands of immigrants. Moreover, precious metals promoted economic growth and opportunities not only where mined but also along the trade routes. The gold of Minas Gerais generated an economic golden age throughout coastal Brazil and waves of Portuguese immigration. Silver transport from Mexico to Spain turned Havana into a major port in the Americas and led to the development of a precocious service economy that by the eighteenth century had turned Cuba into a major magnet for immigrants. The export of Peruvian silver through the River Plate in the second half of the eighteenth century pushed the Argentine gross domestic product and immigration rates above those of Mexico or Peru. 
The free and spontaneous migratory currents that these pull factors prompted were rare outside Ibero-America before 1800. Elsewhere, imperial powers struggled to induce subjects to move to the colonies and ended up relying on various forms of forced or semi-voluntary migrations. Over two-thirds of the 600,000 British that arrived in the New World before 1780 did so as indentured servants and more than 60,000 as convicts (Stewart, 2015; Morgan, 2001; Jordan; Walsh, 2008). Before 1800 , there were only a few thousand British in India other than soldiers (Games, 2002, p. 36-8). French authorities depended on indentured servants (engagés) and prisoners to maintain a European presence in the Antilles. ${ }^{3}$ They recruited engagés, soldiers, women from orphanages and asylums (the so-called fils du roi) to settle Quebec and Louisiana (Moogk, 1994). The Dutch had to rely on sailors for the East and West Indies Companies (half of whom were non-Dutch), soldiers, indentured laborers, orphans, and foreigners to settle their colonies (Kruijtzer, 2008; Silva, 2011). Russians had to rely on the forced transportation of convicts and serfs to colonize Siberia (Lincoln, 2007). The Portuguese also had to recur to exporting orphans, reformed prostitutes, and convicts to populate their non-American colonies (Coates, 2001; 2014); and the Spanish Crown used convict labor to settle its African outposts and attempted to send settlers and families to the Philippines with little success (Pike, 1983; Lagarde, 2008).

By comparison, when it came to populate the Americas, Spain and Portugal not only did not have to rely on indentured servants, convicts, and foreigners, but the supply of willing emigrants was so high that they had to restrict, rather than promote, departures (Slicher Van Bath, 1986). ${ }^{4}$ Spain restricted emigration to the Indies early on, and Portugal in 1720,

${ }^{3}$ See Huetz de Lemps (1991) and Debien (1951), which includes a list of indentured servants, their place of origin, sex etc.

${ }^{4}$ The Portuguese did use convicts to settle the inhospitable frontier regions of Pará and Maranhão but in limited numbers (less than 850 during a span of 70 years; compared to 54,000 British convicts sent to the US during a similar period) (Coates, 2014). 
at the peak of the gold boom in Minas Gerais. Despite these restrictions, about 900,000 Spaniards and 700,000 Portuguese made it to the New World during the colonial period. Moreover, the common idea that these were just single men, in comparison to the family-based movement to British North America, originated in stereotypes about conquistadors and the exceptional cases of New England Puritans and Pennsylvania Quakers. In reality, the proportion of women in the British and Iberian transatlantic movements was similar: between 20 and 25 percent. $^{5}$

This migration was massive enough and gender-balanced enough to permit the formation and reproduction of the colonizers' culture with a transformative force unprecedented in the modern history of colonialism outside the Anglo colonies of settlement and Quebec. At the most primary level, Iberian colonialism transformed the physical ecology of the Americas to a degree unknown in the history of European colonialism in the Afro-Asiatic world, or for that matter of Arab colonialism in North Africa. This transformation of the hemisphere's biota had momentous demographic, economic, and social consequences. At the microscopic level, imported pathogens decimated the indigenous population in a demographic catastrophe of a magnitude without parallel anywhere else with the possible exception of the medieval Black Death and the Spanish influenza pandemic of $1918 .{ }^{6}$ Scores of new plants and animals, along with imported technology, transformed elemental aspects of quotidian life that went from eating habits, clothing, naming patterns, domestic architecture, work, and leisure to land use, specifically the introduction of extensive agriculture, ranching, and equestrian cultures. Whether they

\footnotetext{
${ }^{5}$ For the sex ratio of various colonial migrations see Moya (2015a).

${ }^{6}$ The historical literature on the demographic consequences of the European conquest of the Americas is extensive; for a review see Armus and Denis, (2011). The bubonic plague of 1347-51, or Black Death, killed an estimated 75 to 200 million people in Eurasia with local death rates between 30 and 80 percent (Alchon, 2003). The influenza pandemic of 1918-19, known as "Spanish" because news about it in Europe came mainly from Spain, one of the few neutral countries and thus one of the few without a censored press, actually originated in China, or most likely, the United States, and had a death toll estimated between 30 and 60 million (Killingray; Phillips, 2003).
} 
were estancias in the pampas, fazendas in Brazil, haciendas in IndoAmerica, or plantations in Afro-America, the prevalence of latifundia, a land-tenure system dominated by large estates, shaped rural space and social relations in most of Latin America. The precocious development of commercial agriculture - whether export-oriented or domestic became another distinguishing historical characteristic of the region. Renaissance Mediterranean urban planning with its central plazas and checkerboard grid shaped space in towns and cities from Chile to Mexico. Iberian law imposed a unifying legal (and legalistic) culture that affected anything from marriage and domestic relations to inheritance and commercial contracts. Roman Catholicism had a unifying and lasting effect on the entire region both as a set of beliefs and practices and as a public institution.

The Iberian languages imposed a degree of linguistic unity that sets Latin America apart from any other continent. In the Spanish possessions, the fact that Andalusia, Estremadura, and New Castile - rather than Spain in general - supplied the majority of arrivals during the first century of colonization, shaped and unified American Castilian. Despite the existence of regional accents, Spanish and Portuguese in Latin America developed no creole languages similar to the French-based creoles of Haiti, Guiana, or New Caledonia; or the English creoles of Belize, Guyana and the West Indies; or the Papiamento of the Netherland Antilles. Indeed, it is revealing that with a single minor exception (Palenquero, a SpanishBantu patois spoken by a few hundred descendants of runaway slaves in a village southeast of Cartagena) the only creoles in Latin America are English-based languages introduced by West Indians immigrants in the Atlantic coast of Central America and the Colombian islands of San Andres and Providencia. The absence does not obey any intrinsic trait of the Spanish and Portuguese languages or of Iberian imperialism in general. After all, a Spanish-based creole developed in the Philippines (Chabacano) and eighteen Portuguese creoles have emerged in Africa, 
Asia and even the Americas (Portuguese accounts for over half of the vocabulary of Papiamento in Aruba, Bonaire, and Curacao, and for a quarter of Saramaccan in Surinam). ${ }^{7}$

A comparison of current saturation level of colonial languages worldwide highlights the distinctiveness of the Iberian colonial experience in the Americas. Over 99\% of the native-born population of Brazil speak Portuguese as a first language (L1 speakers) and the same is true of Spanish in 14 Spanish American countries. In the others, it ranges from a low of $70 \%$ in Paraguay, to a range of 86-88 percent in Bolivia, Peru, and Guatemala, and a high of 93\% in Panama (Fernández; Roth, 2006). By comparison, Portuguese has virtually disappeared from the Lusitanian ex-colonies in Asia and less than $6 \%$ of the population speak it as a first language in Mozambique. Spanish has vanished from the Philippines and only $14 \%$ of the population speak it as a first language in Equatorial Guinea. Less than one percent of the present-day population of English ex-colonies in South Asia and Africa (other than South Africa), and of French ex-colonies in Africa are L1 speakers of English or French (Crystal, 2004; Simons; Fennig, 20178). Less than 15\% of the population of the Russian ex-"republics" of Uzbekistan, Turkmenistan, Tajikistan, Kyrgyzstan, Azerbaijan, Armenia, and Georgia speak Russian as a first language. Dutch has practically disappeared from Indonesia and French from the Middle East and Indochina. Even at their highest levels, such as the $70 \%$ of the Belarusian population that are L1 speakers of Russian, the saturation of colonial languages outside of Latin America and the British/ French colonies of settlement are still comparatively low.

These drastic contrasts in the usage of colonial languages and the absence of Spanish or Portuguese creoles in Latin America reflect a broader phenomenon that transcends linguistics: the cultural breadth and depth of Iberian colonialism in the New World. Its impact runs the gamut from the most primary and physical to the most ethereal. It is palpable in the

${ }^{7}$ For colonial creoles of Spanish and Portuguese, including articles on Palenquero, see Schwegler et al. (2016).

${ }^{8}$ Also used for the other cases in this paragraph. 
ecology, the flora and fauna, agriculture and husbandry, food and cooking, urban space, public and domestic architecture, politics, the law, language, literature, music, high and folk art, naming patterns, and just about every aspect of social life. Even some Latin American cultural artifacts that came to be seen as quintessentially indigenous - such as the bowler hats, traditional polleras (skirts), and charangos (small guitars) of the Andean region - are actually Castilian imports from the sixteenth century. Indeed, the Iberian cultural imprint often became invisible precisely because it was so deep and buried in time that it appeared to most observers as local, natural, and indigenous. The emphasis of the historiography on the Amerindian and African components of Latin America in the last few decades has contributed its share in making such an omnipresent and presumably obvious element, less visible.

This has obscured two factors crucial in defining Latin America as a meaningful category beyond mere geographical adjacency. One is internal. The Iberian cultural imprint is the principal commonality that warrants including countries and regions that are drastically different in ethno-racial composition, levels of economic development, and social structure, in the same category. The other is external. The Iberian imprint distinguishes Latin America from the rest of the so-called global South. Nowhere in the AfroAsiatic world did European culture spread so widely and seep so deeply.

This transformative colonization reflects specific conditions and processes. One could be that Iberian colonialism in the Americas began earlier and lasted longer (some three centuries in the mainland and four in Cuba and Puerto Rico) than most other cases. Yet that is not enough. Arab invaders conquered the Maghreb a few decades before entering the Iberian Peninsula in $711 \mathrm{CE}$. Unlike in the latter, they were never expelled by a native Reconquista, nor by wars of independence as happened to the Spanish and Portuguese in Latin America. Yet after thirteen centuries of Arab and Arabized colonial presence, a smaller proportion of the population speaks Arabic as a first language in Morocco (60\%) and Algeria (70\%) than 
speak Spanish in even the most indigenous countries of Latin America. Oghuz or Muslim Turks conquered Anatolia in the 11th century CE. Yet after a millennium of Turkish rule, the genocide of a million Armenians and half-a-million Greeks in 1913-1923, and the mass expulsion of another two million, $15 \%$ still do not speak Turkish as a native tongue, do not consider themselves Turks, and want to secede from Turkey by peaceful or violent means. At the time of Angola's independence in 1974, and after five centuries of Portuguese colonization, only one percent of its rural population spoke Portuguese regularly (Bender, 1978). The imperial presence of the Dutch in Indonesia, the Spaniards in the Philippines, or for that matter, the Arabs in Spain, began as early or earlier than the Iberian empires in Latin America and lasted longer yet their long-term influence was significantly smaller.

Two other factors, beyond the age and length of imperial rule, can explain the unusual transformative capacity of Iberian colonialism in the Americas. The first is the gap in technology and material culture between the conquerors and the conquered. The lack of connectivity internally in the Americas and between it and the rest of the world was result, part, and cause of this gap and of the related decimation of the aboriginal population by arms and germs. This is a very different encounter than those between Arab invaders and Berbers in the Maghreb, Turks and the pre-Turkic population of Anatolia, or the British and French and their colonies in Africa and Asia, where the material and immunological gap was much narrower or even benefited the conquered. The Iberian conquest actually shows greater resemblance to the expansion of Austronesians and Bantus three millennia ago into the Pacific and the southern half of Africa respectively at the expense of groups with limited knowledge of metals, no pack animals and wheeled vehicles, and little immunity to external diseases.

The second key explanation is the relative thick and long-lasting inflow of settlers with an important female component. In many regions, 
Iberian colonizers and their descendants came to represent the majority. The largest of these regions is the temperate belt of South America. But others developed elsewhere, such as in Antioquia and Caldas in Colombia, the Altos de Jalisco and other areas in northern Mexico, the central highlands of Costa Rica and Puerto Rico, Merida in Venezuela, and western and central Cuba. Where this did not happen, Iberians and their descendants accounted for a larger proportion of the population than is often assumed.

Scholars of Latin America often decry the region's ideology of whitening and the associated tendency to minimize or negate, and thus conceal, the African and indigenous presence. Yet, the way racial categories are constructed and perceived in the Americas actually underestimates, and conceals, the European component. These constructions are particularly arbitrary and illogical but have been naturalized to a degree that they cloud our intellect and perception. They explain why we can consider, see, and refer to, say President Obama, as black, African-American, and nonwhite but not as white, Euro-American, or nonblack, although logically and visually both options are equally valid, and in the case of Obama, the latter comes closer to the truth culturally since he was raised by his white mother and family and saw his African father only once in his life. The arbitrariness reached a high point in North American notions of hypodescent or "one-drop rule," where one black ancestor and thirty-one white ones made you legally black. But the logic is the same in Latin America, which, after all, first developed the racial taxonomies of the Americas and their vocabulary: negro, mulatto, quadroon, tercerón (octoroon), and an infinity of local terms all meant to signify non-whiteness. All over the Americas, these taxonomies emerged not just to classify, as in Linnaean botany, but also to rank and exclude. Whiteness, therefore, functioned as both a default and a gatekeeper.

This explains why Latin Americans of mixed origins with significant, and even predominant, European ancestry are seen and classified, and see 
and classify themselves, as non-white. A study of high school students in Rio de Janeiro showed that the European proportion of genomic ancestry was $80 \%$ for those who described themselves as mulattoes or brown (pardo), and $52 \%$ for those who described themselves as black (preto) (Santos et al., 2009). Similar results appear when others do the classification. Brazilians identified as pardos by evaluators based on skin color, are genetically $62 \%$ European and 26\% African (Muniz et al., 2008). The perception of North American scholars appears even more distorted. To give but one example, books and articles published in the United States consistently describe Dominicans as overwhelmingly (90\%) Afro-descendant and chastise them for "denying the African component of their DNA, culture, and history". ${ }^{9}$ Yet, Dominicans are more Hispanic than African by most cultural criteria, history, and collective DNA, which is 52\% European and $40 \%$ African (Estrada-Veras et al., 2016). This is no fluke. Autosomal DNA studies often show a higher European component in the genomic composition of Latin American countries, particularly those usually seen as non-white, than census figures or scholarly estimates. The European percentage of the gene pool is about 84 in Uruguay; 79 in Argentina; 72 in Cuba; 71 in Brazil; 63 in Costa Rica, Puerto Rico, Venezuela, and Colombia; 57 in Chile; 41 in Ecuador; 34 in Mexico; 26 in Peru; and 12 in Bolivia (Salzano; Sans, 2014; Corach et al., 2010; Watkins et al., 2012; Homburger, 2015; Hidalgo et al., 2005). As in all places with a history of conquest, and to a lesser degree of labor immigration, the genomic input of the victors and arrivals comes disproportionately from the male side. What is distinctive about Latin America is the magnitude of the input. It is immensely higher than the European genetic input in their African and Asian colonies, than the Arab input in the Maghreb, and

${ }^{9}$ Gates (2011) stresses both overwhelming black component of the Dominican Republic and its denial. Ricourt (2016) sets the question of "Why do Dominicans deny the African component of their DNA, culture, and history" in the first sentence of the book. Simmons (2011) broaches the same question and celebrates that Dominicans are catching up with the United States by "slowly embracing blackness and ideas of African ancestry." 
significantly higher than that of the Turkic conquerors in Turkey, where they account for $13-15 \%$ of the country's gene pool (Gomez-Casado et al., 2000; Hodoğlugil; Mahley, 2012). Only in the British colonies of settlement and in Quebec did colonizers have a greater demographic, and thus cultural, impact.

The density and breadth of the Iberian cultural influence in the Americas had two important consequences. One was that it made the Iberian Atlantic during the colonial period a socio-cultural space rather than simply a section of two empires, or of one during the union of the Spanish and Portuguese Crowns (1580-1640), with return and circular migration sustaining transatlantic links. The other is that it enabled the continuity of the Iberian Atlantic as a socio-cultural space long after it had ceased to exist as a political unit. After all, most Spaniards and Portuguese arrived to the Americas after the emancipation of the colonies. Their back and forth movements and transatlantic family connections promoted greater migration and connectivity. They continued the process of Iberianization in the Americas. So did Iberianized natives of various races who in many cases were not themselves of Iberian origin. Indeed, the Hispanization of the most indigenous regions of Latin America took place mainly in the postcolonial period and particularly in the twentieth century with growing urbanization, internal mobility, expanding national states, public education, and mass media. This resembles the case of Angola, whose Lusitanization sped after the departure of the colonizers, with the proportion of the native population that spoke Portuguese as a first language rocketing from $3 \%$ at the time of independence to $40 \%$ today. In most of Latin America, however, strong Ibero-creole culture had already developed by the end of the colonial period. These had become hegemonic enough to evolve into shared national cultures and prevent, as we will see, the formation of permanent subcultures by non-Iberian postcolonial arrivals. 


\section{The African Slave Trade}

The force transportation of 12 million Africans across the Atlantic between 1492 and the middle of the nineteenth century surpassed arrivals from Europe four to one and represents the first truly massive transoceanic movement in human history. ${ }^{10}$ Latin America received $58 \%$ of this nefarious inflow with $45 \%$ going to Brazil and $13 \%$ to Spanish America. However, the numbers and proportions changed radically over time. During the first century and a half of the traffic (1492-1650), Latin America absorbed $97 \%$ of the trade, with the silver-rich Spanish mainland colonies receiving $76 \%$ of the slaves, the Spanish Caribbean $6 \%$, and Brazil $15 \%$. In the next century and a half (1650-1800), the sugar plantation boom in the British, French, and Dutch West Indies diminished the Iberian share to $36 \%$, almost all of it Brazilian as the proportion headed to the Spanish colonies shrank to $3 \%$ of the total. With the collapse of the sugar economy in Saint-Domingue during the Haitian Revolution and the abolition of the slave trade in the British Empire in 1807, Latin America again became the principal destination, receiving $88 \%$ of all slaves imported to the New World during the 19 th century. ${ }^{11}$

The destination of slaves during this second period of Iberian domination, however, shifted significantly. While slaves imported to Spanish America had outnumbered those imported to Luso-America six to one during 1500-1650, in the 19th century those heading to the latter outnumber those going to the former three to one. Within Brazil the destination of the traffic moved southward in three stages. During the first half of the seventeenth century, Pernambuco had received over $80 \%$ of the traffic. Between 1650 to 1800 , Bahia dominated as it imported

\footnotetext{
10 The East African slave trade across the Indian Ocean and the Sahara was as voluminous as the one across the Atlantic, but it took place over a millennium rather three centuries, so its intensity was much lower. See Campbell, 2004 and Wright, 2007.

11 The figures about the origins and destination of the transatlantic African slave trade over time are based on my analysis of raw data on 35,000 trips of slave ships available at the Trans-Atlantic Slave Database: <www.slavevoyages.org $>$.
} 
two-thirds of the slaves (Verger, 1968). Rio de Janeiro received a similar share during the 19th century as coffee production there, and later in Sao Paulo, increasingly replaced sugar and the northeast as the most dynamic economy in the country.

Shifts in destination within Spanish America were equally noticeable. Within the Spanish American mainland, routes shifted southward as the Rio de la Plata replaced Cartagena and Veracruz as the main entry point of slaves heading for the silver regions of Upper Peru. As many historians have noticed, Buenos Aires and Montevideo, cities that became later associated with European immigration, were the principal slave ports in the Spanish Empire during its last decades in the American mainland (Borucki, 2015). But this seemingly eye-opening statement is deceiving because Spain's mainland colonies at the time received less than onetenth of one percent of the total African slave trade so being the "main slave ports" did not mean much demographically.

More striking is the surge of Cuba. Although the first African slaves arrived with Columbus in 1492, less than six thousand came in the next two and a half centuries, a number that represented just $1 \%$ of all the slaves going to the Spanish colonies and one-tenth of one percent of those going to the Americas in general. ${ }^{12} \mathrm{Up}$ to the middle of the eighteenth century, the island had been mainly a colony of European settlement, not much different from New England or Pennsylvania except that it was richer thanks to its role as entrepôt between the silver of Peru and Mexico and Spain. The precocious service economy this engendered made Cuba probably the most urbanized society in the world around 1800, surpassing the urbanization rates of England and the Netherlands at the time. The relative absence of slaves reflected the scarcity and small size of sugar plantations compared to Hispaniola during the sixteenth century; the English, French, and Dutch Lesser Antilles during the seventeenth; and Jamaica and Saint-Domingue during the 1700s (Moya, 2013a).

12 Data from < www.slavevoyages.org $>$ and from Aimes (1907). 
Several events and processes would change that at the turn of the 19th century. The Haitian revolution destroyed the most productive sugar complex in the world. Demand during the Napoleonic Wars raised prices for the commodity. The wars of independence in Mexico centered in the Bajío, the core of the mining industry, demolishing most of the mines and ending Cuba's profitable role as way station between the silver of the mainland and Europe. All this, along with the availability of appropriate high-clay lowlands in the island, and a technological revolution in production (iron mills, steam engines, enclosed furnaces, vacuum pans, and railroads) turned Cuba into the world's principal producer of sugar in a relatively short time. By 1806 its production had surpassed Jamaica's, by the mid-1820s it exceeded Saint-Domingue's at its peak, and by the middle of the 19th century it accounted for $31 \%$ percent of the world's total output despite the growth of beet-sugar production in Europe (Monzote, 2008).

This sugar boom coincided with a transatlantic wave that brought 780,000 African slaves between 1790 and the mid-1860s, a number that accounted for $95 \%$ of those going to Spanish America and for one-fifth of the total transatlantic traffic. The impact was wide ranging. It increased and Africanized the population. It transformed an economy based on peasant production, service, and trade into one that was mixed but driven by a mono-cultural plantation complex. It changed a system of social relations based on free labor with some slaves into one where slavery became omnipresent (Bergad, 2007). The resident slave population increased from 4,000 in 1760 to 400,000 in the 1840s. By the end of that decade, efforts to bring other bonded workers surfaced as Cuban planters brought in hundreds of enslaved rebel Maya Indians from Yucatan and the first of the 150,000 coolies that arrived from Canton during the next three decades, giving the island the largest Chinese population outside of Asia (Yun, 2008; Corbitt, 1971). 
The late surge of the slave traffic distinguished Cuba and Brazil from the rest of the Americas. It turned them into the most important and socioculturally complex slave societies of the 19th century. Some $92 \%$ of all the slaves that entered Cuba did so in the 19th century. The proportion for Brazil was lower (55\%) but still higher than any place other than Cuba, and the proportion for Rio de Janeiro and the South was significantly higher (78\%). In the rest of Latin America, most of the slave trade had taken place much earlier (before the 1650s). Most of the black population therefore had been native-born for generations and, given the accumulation of high rates of manumission, free. ${ }^{13}$ By the early 19 th century, eight-tenths of Afrodescendants in Spanish America outside of Cuba were free, compared to less than a third in Cuba and Brazil (Klein, 1986; Soler, 2005). Yet, this placed Cuba and Brazil in the middle of the spectrum of liberty in the New World. After all, the proportion of free people among the black populations of the U.S. South and the British and French West Indies ranged between 3 and 5 percent. This turned Cuba and Brazil into more complex places that were neither slave societies nor free societies with a few slaves. Even within the same extended family, one could find plantation slaves, those who worked independently and paid their masters a share of their income, recently manumitted persons, people who have been freeborn for generations, and even ex-slaves slave-owners.

The wave of arrivals also turned Cuba and Brazil into societies of African immigration and an anomaly in the history of African identity-formation in the Americas. While every other destination on the western side of the Black Atlantic witnessed a trend towards a generic racial black identity during the 19th century, Cuba and Brazil saw an opposite move towards stronger and more sharply defined African ethnic identities. Religion, language, music, confraternities, and other forms of sociability came to be defined not only by the larger Yoruba and Bantu divide but also by other

${ }^{13}$ For the concentration of the slave trade in Spanish America before the middle of the seventeenth century, see Bennett (2003), Bowser (1974), Blanco (1998), and Newson and Minchin (2007). 
African ethnicities. ${ }^{14}$ Unlike most other plantation regions in the Americas during the 19th century, Cuba and Brazil were not simply places with a large black population. Blacks were actually more numerous in the United States and represented a larger proportion of the population in most of the Caribbean, including the Atlantic coast of Central and northern South America and even the Pacific coasts of Colombia, Ecuador, and Peru. What distinguished Cuba and Brazil was their position as societies of contemporary African immigration, including women who accounted for three-tenths of the inflow, and the resulting intensity of African culture.

It is true that in terms of the actual movement, its lack of volition, and its market component, slave traffic resembled more trade than migration. But the actual movement is a small portion of the immigration experience and in terms of the longer process of adaptation and collective identity formation, the experience of slaves resembled that of free immigrants in various ways and these are most visible in Cuba and Brazil precisely because they were the last societies of African mass migration in the Americas. ${ }^{15}$

One similarity between bonded and free migrations is the attempt of newcomers to form social networks of solidarity based on micro-region of origin. The resemblances are many. Among both the free and the bonded, most of these networks were informal and left few records. In both cases, they also included more institutional arrangement in the form of beneficence associations. The example of the Abakua society, founded in the town of Regla in Cuba in the 1830s, illustrates the recurrent patterns. As with the landsmanshaftn of Jewish immigrants or other immigrant hometown associations, it was founded not by an ethnic group in general, but by those from a specific origin, in this case Efiks from the Cross River region of southeastern Nigeria. As among many of the landsmanshaftn, it was a fraternal association restricted to men. As the tongs of overseas Chinese

${ }^{14}$ For a discussion of the scholarly literature on slavery and African culture in Brazil see Reis and Klein (2011).

${ }^{15}$ For an attempt to move beyond a single focus on slavery and examine the African presence in the Americas as a history of migration and adaptation, see Moya (2012). 
or many Irish immigrant county associations, it was a secret society. ${ }^{16}$ The institutional strategy of this and many other confraternities of African ethnic groups in Cuba and Brazil also resembled that of immigrant mutual help societies anywhere: members would pay into a mutual fund from which they could draw benefits through various mechanisms of allocation meant to prevent freeriding. Indeed, the members of these associations usually named them "sociedades de socorros mutuos" (mutual aid societies). As in other cases, the criteria for membership tended to expand with time to include individuals from the broader ethno-linguistic group and at times outsiders connected to members by non-ethnic ties. ${ }^{17}$

Specific African ethnicity framed strategies of adaptation. In Brazil, the Bantu, originated in the Portuguese colonies of Angola and to a lesser degree Mozambique, arrived early and often semi-Lusitanized, and formed a large and multi-generational majority accounting for seven-tenths of Africans in the country (Ferreira, 2012; Slenes, 1999). This gave them greater familiarity with the local language, culture and ways, and much deeper and broader social networks. Although they had rebelled and formed the largest settlement of runaway slaves in the Americas during their early days in Brazil in the beginning of the seventeenth century, with time their accumulated social capital facilitated strategies of adaptations and negotiations rather than outright resistance. They were more likely to procure better positions within the system (overseers, domestic and urban occupations, better jobs in the plantations) than other groups, access the legal system, and be manumitted. By contrast, the Hausa and northern Yoruba from what is today Nigeria, arrived late, from non-Lusitanized regions, and as Muslims, which increased their alterity. With few roots in the local society, no multi-generational connections, and little knowledge of local ways, one of the few strategies of coping with slavery available to them was frontal revolt. Not surprisingly, Muslim Hausa and Malé, a

${ }^{16}$ For one of the most recent and complete studies of the Abakua and other secret associations see Miller (2009).

${ }^{17}$ For a discussion of immigrant associational practices in general see Moya (2005). 
term for mostly Yoruba Muslims, carried the largest slave rebellions in nineteenth-century Brazil without any support from the Bantu and their creolized descendants. ${ }^{18}$

Diverging ethnic strategies of adaptation in turn led to, as they did among free immigrants, to the formation of ethnic stereotypes. The Malé and the Bantu constructed narratives to explain their divergent approaches. The former defined themselves as courageous and principled while denouncing the Bantu as cowardly and submissive. The latter saw themselves as sensible and ingenious while labeling the Malé stubborn and obtuse. Similar stereotypes surfaced in Cuba, where the Yoruba were also later arrivals, had fewer local connections, and were seen as more rebellious. Esteban Montejo, a runaway slave whose life history was recorded, maintained that the "Lucumí (Yoruba) and Congolese (Bantu) did not get on." He described the former as "the most rebellious and courageous slaves" and the Bantu as "cowardly as a rule, but strong workers who worked hard without complaining [suggesting a strategy of adaptation]. There is a common rat called Congolese, and very cowardly it is too." (Barnet, 1994, p. 32).

Brazil and Cuba also exhibit two other common elements in the construction of ethnic stereotypes in immigrant societies: the tendency to define the physical and phenotypical traits of the immigrants and to establish cultural hierarchies among them. For the famed Brazilian anthropologist, Gilberto Freyre, the Sudanese (among whom he included Yoruba, Hausa, and Mandinga) were among the tallest people in the world compared to the "low, squat people" of southern Africa. ${ }^{19}$ Connecting stature and status, a common practice in these types of discourses, Freyre went on to describe the Sudanese as culturally and morally superior not only to other African slave groups but even to the local Brazilian

${ }^{18}$ For a rebellion in Bahia by Muslim Hausa slaves in 1814 and another in 1835 led by the Malé, see respectively Schwartz (1997) and Reis (1993).

${ }^{19}$ Freyre, The Masters and the Slaves (1986). The book was originally published in 1933 as Casa-Grande e Senzala. 
population and the Portuguese (Freyre, 1986, p. 281). These arguments echoed those made by Nina Rodrigues, one the founders of Brazilian anthropology in the late 19th century, who took for granted the cultural superiority of the Yoruba and other northern people over the Bantu but argued that contrary to established opinion (and actually, historical fact), the former were as numerous in Brazil as the latter. The tendency to employ ethnic stereotypes that assigned and mixed physical and character traits, however, was not limited to anthropologists and elites. It crossed class and racial boundaries as the descriptions by the runway slave Esteban Montejo indicate:

The Congolese were black-skinned, though there were many of mixed blood with yellowish skin and light hair [suggesting greater assimilation]. They were usually small. The Mandingas were reddish-skinned, tall and very strong. I swear by my mother they were a bunch of crooks, too! They kept apart from the rest. The Gangas were nice people, rather short and freckled. Many of them became runaways. The Carabalís were like the Musundi Congolese, uncivilized brutes. They only killed pigs on Sundays and at Easter and, being good businessmen, they killed them to sell, not to eat themselves. From this comes a saying, "Clever Carabalí, kills pig on Sunday." (Barnet, 1994, p. 37).

As was the case with free immigrants in the Americas, ethnic ties tended to decline with time and give way to wider identities. From an initial association with hometown or micro-regions of origin, collective identities fused into broader but still African-based groupings that came to resemble national identities. It is probably not a coincidence that black confraternities in Cuba became known as "sociedades de nación" as in the "Sociedad de Socorros Mutuos de Nación Lucumí" or the "Sociedad de socorros mutuos del antiguo Cabildo de la Nación Carabalí." (Miller, 2009, p. 274). As was the case with European immigrants from emergent nation, such as Italians, these "national identities" were partially a diasporic construction. Lucumí is the Cuban term for Yoruba but, as several historians have shown, the notion of a Yoruba identity barely existed in Africa in the 19th century as people's endonyms referred to specific localities rather a pan-ethnic 
identity (Doortmont, 1990). Yet rather than pure inventions, these identities represented creations that fused pre-migration traits, elements from other African backgrounds found in the Americas, and Ibero-creole components. As the African inflow ended, languages were lost and creolization accelerated. But African ethnic identities survived mainly in symbolic forms, sometimes in exaggeratedly self-conscious expressions - not too dissimilar to the resurgence of white ethnicity in the United States in the 1970s - and sometimes unknowingly. ${ }^{20}$ That was the case of a Cuban neighborhood club where an Australian musicologist recently found that, unknown to its members, the songs and dances they performed originated with a small sub-group of the Gangá (the Gangá-Longobá) from a village in Sierra Leone (Christopher, 2013). In this case, as in many others of migrants after several generations, we have ethnic persistence without ethnic consciousness, memory or identity.

A final distinctive characteristic of the surge of plantation slavery in Brazil and Cuba during the first half of the 19th century is that, despite its dynamism, it never overwhelmed the rest of the economic and social structure. Unlike in the British and French West Indian colonies, slaves never represented a majority and their proportion of the population dropped as sharply as it had risen (in the most extreme case of Cuba, from $26 \%$ in 1774 to a peak of $41 \%$ in 1827 and back to $26 \%$ by 1862). The free colored peasantry not only survived the sharp advent of slavery but increased their ranks both in absolute and relative numbers after the mid-nineteenth century. And so did the white rural and urban working classes with the arrivals of millions of European immigrants in the next eight decades. Like the United States, Brazil and Cuba developed thus from dual roots as societies of slavery and free settlement, of oppression and opportunities, contradictions that have lasted to the present.

${ }^{20}$ For the resurgence in the 1970s of white ethnicity in the United States, see Alba (1990). For a similar process among Afro-descendants in Cuba, see Vaughan (2012, p. 31, 39, 43) for symbolic performance of specific African ethnicity, and Clealand, (2017). 


\section{Postcolonial Migrations}

The largest migrations to Latin America during the first half of the nineteenth century were only partially postcolonial. About 70,000 Europeans entered Cuba during that period, when the island was still a colony. But some of these inflows were postcolonial in origin: Spanish and French refugees fleeing from the collapse of colonial regimes in the mainland and Saint-Domingue (Berenguer, 1979). ${ }^{21}$ But the majority came directly from Spain: tobacco farmers from the Canary Islands, Galician laborers, and Catalan merchants among others. The largest European flows to Cuba during the second half of the century were categorically colonial: about 430,000 Spanish soldiers sent to the island to put down anti-colonial revolts. As Cuban historians have shown, the Spanish army became a mechanism of immigration. About one-third of the soldiers either managed to stay in Cuba or returned some years later, and they brought over family and fellow townsmen (Fraginals; Masó, 1999).

The Europeans who arrived between the mid nineteenth century and the world depression of 1930, represent the largest population inflow in Latin America history (Table 1). This movement accounts for seven-tenths of all the people who ever came to Latin America, and one-quarter of all the Europeans who left their native continent during the period. The regional sources, however, differed from the European flow elsewhere. Emigration to Australia, New Zealand, Canada, and South Africa originated overwhelmingly in northwestern Europe, particularly the British Isles. In the United States, the stream originated also from northwestern Europe almost exclusively before 1880 and more than half during the entire period. In Latin America, the inflow was heavily southern European (Table 2). Italy alone accounted for almost four-tenths of all newcomers, Spain for three-tenths, and Portugal for one one-tenth. The two peninsulas of southwestern Europe thus supplied close to 80 percent of the arrivals. Regional origins within these southern European countries were, however, heavily northerner.

${ }^{21}$ See Murillo (1999), for letters written by Spanish immigrants in Cuba, 1808-1829. 
Table 1. Migrations to Latin America, 1492-2015

\begin{tabular}{lcc}
\hline & Number & \% of Total \\
\hline From Africa to Brazil & $3,527,000$ & 15 \\
From Africa to Spanish America & $1,235,000$ & 5 \\
From Spain to Colonial Sp. Ame. & 900,000 & 4 \\
From Portugal to Colonial Brazil & 700,000 & 3 \\
Postcolonial Asian immigration & 855,000 & 4 \\
Postcolonial European immigration & $16,820,000$ & 70 \\
\hline Total & $24,037,000$ & 100 \\
\hline
\end{tabular}

Source: Moya (2014).

Table 2. Origins of European Immigrants to Latin America, 1820-1960

\begin{tabular}{lcc}
\hline Origin & Number & \% of Total \\
\hline Italy & $6,710,000$ & 39.9 \\
Spain & $5,380,000$ & 32 \\
Portugal & $1,850,000$ & 11 \\
Germany & 470,000 & 2.8 \\
Eastern European Jews & 420,000 & 2.5 \\
Levant & 410,000 & 2.4 \\
France & 360,000 & 2.1 \\
Other Europe & $1,220,000$ & 7.3 \\
\hline Total & $16,820,000$ & \\
\hline
\end{tabular}

Source: culled from various sources listed in Moya (2011).

In the case of Italy, the northern preponderance reflected time of arrival. Unlike European migration in general, which acquired massive dimensions in the U.S. earlier than it did in Latin America, Italian migration to South America reached massive numbers earlier than to the U.S. During the 19th century, the stream toward that region was twice as large as that to North America. By 1900, the Italian community in Buenos Aires was larger than the ten largest in North America combined; and São Paulo, Montevideo, and 
Rosario had more Italians than any U.S. city other than New York. The fact that the upper strip of the peninsula dominated the transatlantic exodus for much of the 19th century gave these early Italian enclaves in Latin America a strong northern imprint. Liguria (the coastal region surrounding Genoa) supplied the single largest contingent in Argentine cities; the Piedmont played that role in the pampas and the Veneto in Brazil. During the 20th century, the Mezzogiorno increased its participation. But northerners retained an overall majority for the entire period in Latin America, in stark contrast to the United States, where southerners accounted for four-fifths of all Italian immigrants (Baily, 1999).

The northern prevalence had even earlier origins in the case of Spain. The Cantabrian seaboard had replaced Andalusia and the South as the main source of migration to the Indies already by the eighteenth century. The trend continued during the 19th century in spite of significant migration from the Canary Islands to Cuba and Venezuela. Basques became the Iberian equivalent of the Piedmontese in the River Plate region: pioneer settlers of the pampas. Their early arrival and concentration on pastoral activities earned them enough wealth and prestige to popularize the idea that the Argentine landed oligarchy was mostly ethnically Basque. Asturians were particularly numerous in Mexico and Cuba. Catalans spread throughout much of Spanish America. These so-called "Jews of Spain" seem to have shared the same dichotomous stereotype as frugal entrepreneurs or radical anarchists. At least the second half of the cliché may not have been an arbitrary invention. Catalans and Jews were the most overrepresented ethnic groups in the anarchist movement both in Europe and in the Americas (Moya, 2004). Galicians became the largest group in all receiving countries. Their numbers and visibility turned gallego into a generic term for Spaniards in Latin America, and into the ludicrous stock character of ethnic popular humor, the Spanish American equivalent of Portuguese jokes in Brazil, and Polish jokes in the United States (Moya, 2003). 
The northern shift among the Portuguese was also well established already in the late colonial period. By the early 1800s, the small region of Minho in the northwestern corner of Portugal provided half of all immigrants in Brazil. Around 1850 more than a third of the Portuguese residents of Rio de Janeiro had been born in the city of Porto, in the Douro region just south of Minho. From this northwestern corner emigration spread to other northern regions, and by the early 20th century Trás-os-Montes in the northeast and the Beiras just to the south had become major sources. Brazil attracted about four-fifths of Portugal's exodus. But this predominance of the northern mainland characterized only the movement to Brazil. As in the case of Italy, we find a sharp contrast between crossings to South America and those to North America, where 70 percent of Portuguese immigrants originated in the Azores and much of the remainder in Madeira and the Cape Verde Islands (Moya, 2015b).

The remaining one-fifth of European immigrants in Latin America who did not come from the Italian and Iberian peninsulas numbered close to 3 million people. Ethnic Germans represented the largest single group. A German geographer estimated the number of his co-ethnics in Latin America at 2 million in 1930. France joined the crossings early and accounted for as much as one-tenth of the stream in the 19th century but diminished its participation after 1900. Eastern Europeans were more numerous but also more difficult to identify because of the multiethnic nature of the polities in the region, their changing boundaries, and even their shifting existence. Argentina, for example, recorded the entry of 180,000 Poles and 48,000 Yugoslavs after World War I but none before. Both groups were simply included then among the 177,000 "Russians" and 111,000 Austro-Hungarians listed in Argentine entry records. In the early 1890s, Brazil fever (gorączka brazylijska) began carrying thousands of Polish peasants to that country and an American geographer estimated that 240,000 "Slavs" resided in the three southernmost Brazilian states in 1930. Jews made such a large proportion of eastern European immigrants 
that ruso and less often polaco, became generic terms for the Ashkenazim in South America. ${ }^{22}$

Other ethnic Europeans came from elsewhere. Afrikaner refugees left South Africa after the Boer War to settle in Patagonia and, in smaller numbers, in Mexico. Some 50,000 people, many of them European-born, left the United States and Canada for Cuba during the first two decades of the 20th century, including rural settlers who founded eighty agricultural colonies. Between 8,000 and 10,000 American Southerners migrated to Mexico and Brazil after the Confederate defeat in the American Civil War.

Many of the 340,000 Middle Easterners who came to Latin America (175,000 of them to Argentina, 95,000 to Brazil, and 70,000 elsewhere) entered as turcos because they traveled with Ottoman passports. But few were actually Turks or even Muslims. The vast majority were members of religious minorities in the Ottoman Empire and its successor states. Sephardim (the descendants of Spanish and Portuguese Jews) from Constantinople, Salonica, and North Africa, and Mizrahim (Arab Jews) from Aleppo and other towns in the Levant migrated to the River Plate region, Brazil, Cuba, and Mexico. Armenians, a group already dispersed throughout the Middle East before moving across the Atlantic, came from a variety of countries. Those in Argentina, which today has the ninth-largest Armenian population in the world $(130,000)$, came mostly from Cilicia in the southeastern coast of Turkey after the massacres of Adana in 1909. Brazil $(40,000)$ and Uruguay $(19,000)$ have the next two largest Armenian communities in Latin America. Palestinians from Bethlehem and a handful of other Christian towns went mostly to Chile, which has the largest concentration of Palestinians outside of the Middle East; Honduras, where they make up 2 percent of the national population; and El Salvador. Syrian-Lebanese, mainly Christian Maronites from Mount Lebanon, moved in large numbers to the classic countries of immigration in South America, particularly Brazil, which has

22 The data on the various immigrant groups in this paragraph and the following is culled from sources listed and described in Moya (2011). 
the largest Lebanese community in the world (Truzzi, 2008). But they found their way to every single country in the Western Hemisphere. Even within the traditional host countries, they moved to regions, such as the Andean Northwest of Argentina and the Northeast of Brazil, where few European newcomers settled.

Besides those who came from the Middle East, about 580,000 Asians came to Latin America before World War II. Six-tenths of these were Chinese and moved mainly to Cuba, Peru, and to a lesser degree northern Mexico. Because male contract laborers accounted for the overwhelming majority, the settled Chinese communities remained relatively small. Japanese arrived later but as family groups so in spite of their smaller numbers, the ethnic communities reproduced much more. The one in Brazil numbers about 2 million, which gives the country the largest population of Japanese origin outside of Japan.

As with the African slave traffic (and as Table 3 shows), European migration headed to all Latin American countries but at the same time it was highly concentrated. About $85 \%$ of the flow headed to the region of temperate South America that stretches from Sao Paulo to the River Plate littoral and the pampas. This reflected a global ecological process. The European exodus represented the largest relocation of population in world history, moving it from the most densely populated temperate regions of the planet to its least densely populated temperate regions. Over ninetenths of the exodus moved towards these "Neo-Europes" - northern North America, southern South America, Australasia, and north central Asia - places with similar climates and ecologies as Europe but so sparsely populated that their total aboriginal population in 1800 was smaller than the population of Switzerland or London (Moya; McKeown, 2011). Indeed, the only places in the tropics to receive significant numbers of Europeans were in Latin America: Cuba and central Brazil. 
Table 3. Destination of European Immigrants to Latin America, 1850-1930

\begin{tabular}{lrc}
\hline Country & Number & \% of Total \\
\hline Argentina & $6,501,000$ & 47.9 \\
Brazil & $4,361,000$ & 32.1 \\
Cuba & $1,394,000$ & 10.3 \\
Uruguay & 713,000 & 5.3 \\
Mexico & 270,000 & 2 \\
Chile & 90,000 & 0.7 \\
Venezuela & 70,000 & 0.5 \\
Puerto Rico & 62,000 & 0.5 \\
Peru & 35,000 & 0.3 \\
Paraguay & 21,000 & 0.2 \\
Others & 50,000 & 0.4 \\
\hline Total & $13,567,000$ & \\
\hline
\end{tabular}

Source: Moya (1998, p. 46).

\section{European Immigration and the "Great Reversal"}

European immigration reversed socioeconomic rank within of the Western Hemisphere. Before 1800, the colonial success stories rested on a combination of indigenous labor and precious metals, or African slavery and tropical cash crops. The silver of Zacatecas and Potosi had turned Mexico and Peru into the shining stars in the firmament of the Spanish Empire. Sugar and slavery had turned Saint-Domingue and Barbados into some of the richest colonies in the world, worth many times more to the French and British than Quebec or the future United States (Dupuy, 1985; Eltis, 1995). In terms of the scale, efficiency, and market orientation of production, the most modern economies in the Americas around 1800 could be found in the mining complex of the Mexican Bajío and in the plantations of the West 
Indies. ${ }^{23} \mathrm{~A}$ century later economic modernity had moved to the factories and commercial farms in regions of European settlement. Free immigration and its accompanying processes had turned the poorest colonies in the Western Hemisphere into its richest countries.

A similar reversal occurred within countries. Argentina's economic center shifted during the 19th century from the Northwest or Andean region that had formed part of the silver mining complex of Upper Peru to the Atlantic-facing and immigrant-receiving littoral on the east. In Brazil, it shifted southward from the plantation economies of Pernambuco and Bahia, to the gold and diamond mines of Minas Gerais in the eighteenth century, and a century later to the previously marginal São Paulo and the South. In the United States, the shift went in the other geographical direction - from the South to the Northeast - but in the same social track from a region of slavery and plantations to one of commercial farms, factories, and immigrants (Moya, 2006).

The shift in the distribution of urban centers in the Americas illustrates this overall reversal. Before 1800, forty-six of the fifty largest cities in the Americas, including the ten largest, were within the silver/indigenous-labor or plantation/African-slaves complexes that formed the colonial cores. By 1910 the largest eleven cities in the Americas, and eighty-one of the top one hundred, were cities in Euro-America. The five most urbanized countries (Uruguay, Cuba, Argentina, the United States, and Canada in that order) were the ones with the highest proportion of European immigrants in their populations. Insofar as modernity, whatever its definition, is unfailingly situated in urban spaces, one can argue that the sites of the modern in the Western Hemisphere shifted during the 19th century from the colonial cores in Indo/mestizo- and Afro-America to Euro-America, the temperate ends of the hemisphere that had also been its socioeconomic margins, and

${ }^{23}$ Tutino (2011) has shown that the mining complex in late colonial Mexico represented one of the most developed capitalist economies in the world at the time. Pomeranz and Topik (1999, p. 215), argue that industrial production may indeed have originated in Caribbean sugar mills. These are among many recent studies that question the assumption that industrialization and capitalism before the $19^{\text {th }}$ century was basically, or even mostly, a European phenomenon. 
to Cuba. Indeed, only the blinders of U.S.-centrism can obscure the fact that, before 1800, the principal sites of modernity could be found not in Boston or Philadelphia but in places like Guanajuato and Salvador (in terms of the technology and market orientation of production) or Mexico City and Lima (in terms of books, theaters, architecture, music, and other cultural products). And only the most equivocal definition of alternative modernities can conceal its evident relocation to places like New York, Chicago, Buenos Aires, Montevideo, and São Paulo that occurred during the 19th century.

Modernity not only shifted spatially but also in its internal content. Economically it shifted - in the new regions of European immigration of the Americas - to a system that was capitalist not only in terms of exchange and commercialization (as it had been in the old colonial core) but also in terms of social relations of production, based on free labor rather than slavery and semi-bondage arrangements. Economic growth acquired here a stronger connection to social welfare. The regions of European immigration developed the largest and most powerful labor movement in Latin America and one of the most powerful in the world. They boasted the highest nutritional levels, the highest life expectancy and lowest mortality, the highest levels of civic participation in mutual aid societies and other voluntary associations, and the highest levels of popular participation in banking and savings. They also had the earliest and most inclusive forms of political participation, the highest literacy rates, and the highest per capita levels of printed material, theater performances, sport clubs and activities, and other cultural products. ${ }^{24}$

These represented the first mass societies in Latin America. Economic and sociocultural resources there were both more abundant and more equally distributed than in the rest of Latin America, and in fact than in most of Europe. By the 1920s, real wages in Argentina and Uruguay surpassed those in every European country except England and Switzerland, which they matched. Water consumption and home-ownership rates were higher

${ }^{24}$ On health indicators, see Moya (1998, p. 150-3); for literacy rates in Latin American countries and globally during the $19^{\text {th }}$ and early $20^{\text {th }}$ century, see UNESCO (1953, p. 200-22) and Newland (1991, p. 378). For theater as a form of mass entertainment, see McCleary (2015). 
than in any country in the Old World. The children of immigrants became, on average, two inches taller than their European-born parents, irrespective of their ethnic origins. The high levels of popular consumption in turn fomented the early development of domestic markets in regions that also had the highest levels of per capita exports in the New World (Moya, 2006).

The impact of immigration was particularly multifaceted in the stretch of temperate South America that runs from Patagonia to São Paulo. The demographic impact here was among the highest in the world. For example, immigrants accounted for 35 percent of the population in Uruguay in the late 1800s, and 30 percent in Argentina on the eve of World I, compared with 20 percent in Australia and 15 percent in the United States. The newcomers and their descendants came to account for over 80 percent of the population in temperate South America. Given their demographic weight, they also had a tremendous impact in shaping the region's popular culture. They diversified a carnivorous diet, turning items such as pasta and wine into national staples. They introduced sports and leisure activities such as bocce, Basque handball, polo, zarzuelas, and soccer. By the early twentieth century, Buenos Aires and Montevideo boasted the largest number of soccer clubs and stadiums in the world along with London (Rein, 2015). This region of South America has won nine of the twenty soccer World Cups ever played. Immigrants introduced musical instruments and styles and shaped the tango. They did not have the institutional power to change the syntax of national languages. But they had the numbers to change them phonetically, the reason why River Plate Spanish sounds like Italian to most foreigners.

As with African arrivals, the preservation of pre-migration cultures differed with circumstances. Those who settled in relatively isolated rural colonies - such as the Welsh or Volga Germans in Patagonia and the Pampas, and Germans in Southern Brazil - were able to preserve their languages and ways for a longer time than those who settled in urban or suburban settings. The arrival of significant numbers of European immigrants in all the settler countries after World War II reactivated links with the homelands 
and pre-migratory identities. Groups, mainly northern European, that had a sense of superiority vis a vis "Latin" culture tended to keep a separate identity longer than those of Southern European origins. Relative national wealth and prestige across time had also an effect. During most of the mass migration period, the receiving countries were perceived as more modern and advanced than most of the sending countries. The children of immigrants often felt ashamed of their origins and wished to identify with the new country. The rising economic and cultural prestige of Southern European countries in the last decades (at least before the 2008 depression), has led to an increase in identification with immigrant origins. Some of it is purely utilitarian (getting EU passports and migrating there for economic reasons). But there are also elements of symbolic ethnic revival.

Nevertheless, by global standards what is striking in Latin American countries of immigration is not the persistence of pre-migratory cultures, habits, and identities but the speed and thoroughness of their erasure. Migrants throughout the world, from Arabs and Gujaratis in East Africa and Ibos and Lebanese in West Africa to Volga Germans in Kazakhstan and Chinese in Malaysia, maintain separate identities and communal structures for generations and sometimes centuries, even when they are not territorialized. Their ethnic identity not only influences mores, manners, and domestic behavior, but almost determines what they speak and eat, where they live, how they earn a living, who they socialize with and marry, and just about every aspect of their private and public life.

Compared to this level of separation and continuity, ethnic persistence in Latin America seems, particularly after the third generation, less consequential, to put it mildly. Linguistically, these host societies have proven to be steamrollers. Third generation immigrants who speak the language of their ancestors are few, and those who speak it fluently rara avis indeed. Yiddish, which had survived for a millennium as an ethnic minority language in Central and Eastern Europe, disappeared in three generations in Argentina, Uruguay, and Brazil (Moya, 2013b). Rates of exogamy are exceptionally high. This is true even 
among groups that were already ethnic minorities and highly endogamous before crossing the Atlantic. More than half of Jews in Argentina, Uruguay, Brazil, and the U.S. marry outside the group, an unprecedented level in the history of a group whose exogamy rates in Eastern Europe, North Africa, and the Middle East around 1930 were below 2\% and today are below 35\% in other diasporic sites such as Australia, Canada, and New Zealand, and under 25\% in South Africa (Erdei, 2014; Reinharz; DellaPergola, 2009). Residential and occupational segregation were never high by international standards and have basically disappeared (Moya, 1998, p. 180-8).

This assimilationist force both reflects and is reflected in notions of citizenship that Latin America shares with the rest of the Hemisphere. All but two of the thirty-eight countries in the New World grant citizenship as a birth right (jus soli), an inclusive form of civic citizenship that allows anyone to become a member of the polity and a national regardless of their ancestry. This stands in stark contrast with the rest of the world where only 11 of 156 countries have jus soli and grant citizenship based on "blood" (jus sanguinis) rather than as a birth right.

The process of absorption was also relatively free of violence in the countries of European immigration. The immigrants and their descendants were too numerous to concentrate either at the bottom or the top of the class pyramid inhibiting the fusion of xenophobia and class resentment or discrimination that has been common in Europe, Africa, and Asia. The high ratio of resources to labor and the exceptional economic expansion of the Neo-Europes mitigated group competition for scarce resources. This plus the prevalence of legal systems based on universalistic principles rather than group rights, and the countries' relatively stable public institutions mitigated inter-ethnic violence. It is telling that the most brutal anti-immigrant episodes in the Americas happened not in countries of European immigration but in the Dominican Republic where about 12,000 Haitians were massacred in 1937, and in the Mexican states of Coahuila and Sonora, where 400 Chinese were killed during the Mexican Revolution. Moreover, the low levels of violence include crime and murder. 
Homicide rates in the countries and regions that received mass European immigration in the nineteenth and early twentieth century - Argentina, Uruguay, and Cuba - are today four times lower than the Latin American average and as much as twenty-eight times lower than in the countries with the highest rates. ${ }^{25}$

The relative smooth integration of European immigrants, however, often came at the expense of nonwhite minorities. As in the United States, later internal and international nonwhite migrations pushed the earlier European arrivals and their descendants out of the lowest socioeconomic and occupational rungs. Mestizos from Andean Argentina and neighboring countries and Afro-Brazilians from the Northeast not only arrived later, in itself a disadvantage; they also arrived with fewer urban skills and at a time, after the 1920s, when the economy was less dynamic and open. Moreover, they increasingly had to compete not with other migrants but with their urbanborn children, who excluded migrants of color through mechanisms that ranged from the hiring of co-ethnics to covert or overt racial discrimination.

This demographic shift produced noticeable socio-cultural and discursive changes. Before the 1930s, most ethnophobic and racialist discourse and discrimination in the Brazilian South and the Argentine littoral had been directed at the latest European arrivals because they made up the bulk of the working class and the poor. As newcomers of color became more numerous and began to replace European immigrants from the lower rungs of the social structure, the direction of ethnophobia began to change also. Increasingly blacks replaced immigrants as the representation of poverty, social pathologies, and danger. Even in Eastern Argentina, where the migrants were mestizos rather than Afro-descendants, they were often referred to as blacks or blackheads (negros or cabecitas negras). In Southern Brazil the racial categories became more dual, more black-and-white literally, than in the rest of the country. There and in Eastern Argentina, "blacks" increasingly became a sort of "permanent other" for the descendants of European immigrants (Moya, 2009).

${ }^{25}$ Calculated from data in reports by the UN Office on Drugs and Crime, <www.unodc.org/ gsh/en/data.html>. 
The impact of immigration was less multifaceted but economically significant in countries that received relatively few immigrants. A small number of German farmers accounted for more than one-third of coffee production in Guatemala in the early 20th century (Wagner, 1991). Palestinian Christians make up less than 2 percent of the population in Honduras, but owned more than half of the businesses in San Pedro Sula already in the 1920s, and a disproportionately high number of industrial and commercial establishments in the country today (González, 1992). The same is true in Ecuador with the Lebanese. People who trace their ancestry to a handful of Maronite villages have been elected to so many local and national offices (including the vice presidency and two presidencies) that political rivals have complained about the "Bedouization of Ecuador." (Roberts, 2000). European immigrants in Mexico made up less than one percent of the population but have played a dominant role in the country's economy and industrialization.

This is true in all other countries of Latin America and the Caribbean where immigration was not a mass phenomenon. The arrivals and their descendants here came to occupy, even when they arrived as humble peddlers, a privileged class position with a sense of cultural superiority. This situation resembled the experiences of so-called middlemen minorities such as the Chinese in Southeast Asia, the Indians in East Africa, and the Lebanese in West Africa, more than those of countries of immigration in the Americas. Yet even in these Latin American countries of limited immigration, the separation between the immigrant-descendants and the native population was never as sharp and tense as in Asia and Africa, in large part because the existence of native upper and middle classes of European (Hispano-Creole) descent made the newcomers less visible.

The reversal of the socioeconomic regional rank within the Western Hemisphere produced by European immigration during the 19th century had a lasting effect. Despite the uneven economic performance of the River Plate countries since the 1960s, the rank in social development indicators within Latin America has shown much continuity over the past century. Those 
countries or regions that immigration had turned into the most urban and socially developed by 1900 (eastern Argentina, Uruguay, southern Brazil, Cuba, and Chile) are still so today. In terms of literacy, life expectancy, infant mortality, nutrition, and other indicators of social welfare, they continue to rank closer to Europe (now at the level of eastern European countries such as Poland) than to the poorer Latin American countries. The "great reversal" thus cemented inequalities between Latin American countries that are greater than those between the latter and the developed West. Today France's GDP per capita is 1.7 times higher than in Argentina, Uruguay, Chile, and southern Brazil. But the GDP per capita in these countries is 3 to 5 times higher than in the poorer Spanish American countries (Honduras, Nicaragua, Guatemala, El Salvador, Bolivia, Paraguay) and 13 times higher than in Haiti.

With this article I hope to have demonstrated that transcontinental migrations, the various forms that they took (Paleolithic first settlement, conquest and colonialism, slavery, free mass movements, and mercantile diasporas), and the way they interacted in the receiving environments, represent the central process in the historical formation of Latin America. This process explains why the Americas are the most multiracial region in the world. Because this multiraciality materialized from movements embodied in structures of great power disparities, it also explains why those regions in Latin America where conquest and slavery predominated have the highest levels of social inequality in the world; and why the regions of new settlement based on free migration have had historically some of the most egalitarian social structures and highest levels of social upward mobility. In terms of cultural formation, the combination of sparse and late aboriginal settlement with an Iberian imperialism that had exceptionally high levels of actual colonialism, i.e. migration and settlement, forged colonial societies that were more culturally homogenous than in most other places. This relative lack of linguistic, religious, and sectarian diversity made it easier for the postcolonial republics to construct national cultures to which later 
arrivals assimilated with exceptional rapidity by international standards. This in turn explains two apparent paradoxes: that the most multiracial region in the world is also the least multicultural; and that region with the greatest racial inequalities is also the one with the lowest levels of ethnic and sectarian separatisms, violence, and genocides.

José C. Moya is a Professor of History in Barnard College, Columbia University, teaching courses in Latin American history, Latin American civilization, and world migration.

Đjmoya@barnard.edu

\section{References}

1. AIMES, S. Hubert. A history of slavery in Cuba. New York: Putnam, 1907.

2. ALBA, Richard D. Ethnic identity: the transformation of white America. New Heaven: Yale University Press, 1990.

3. ALCHON, Suzanne A. A pest in the land: New World epidemics in a global perspective. Albuquerque: University of New Mexico Press, 2003.

4. ARMUS, Diego; DENIS, Adrian L. Disease, medicine, and health. In: MOYA, José C. (Ed.). The Oxford handbook of Latin American History. New York: Oxford University Press, 2011.

5. BAILY, Samuel L. Immigrants in the Lands of Promise: Italians in Buenos Aires and New York, 1870-1914. Ithaca: Cornell University Press, 1999.

6. BARNET, Miguel. Biography of a runaway slave. Willimantic: Curbstone Press, 1994.

7. BENDER, Gerald J. Angola under the Portuguese: the myth and the reality. Berkeley: University of California Press, 1978.

8. BENNETT, Herman L. Africans in colonial Mexico: Absolutism, Christianity, and Afro-Creole Consciousness, 1570-1640. Bloomington: Indiana University Press, 2003.

9. BERENGUER, Jorge. La inmigración francesa en la jurisdicción de Cuba. Santiago: Editorial Oriente, 1979.

10. BERGAD, Laird. The comparative histories of slavery in Brazil, Cuba, and the United States. New York: Cambridge University Press, 2007.

11. BLANCO, Carlos L. Los negros y la esclavitud en Santo Domingo. Santo Domingo: Librería La Trinitaria, 1998. 
12. BORUCKI, Alex. From shipmates to soldiers: emerging black identities in the Río de la Plata. Albuquerque: University of New Mexico Press, 2015.

13. BOWSER, Frederick. The African slave in colonial Peru, 1524-1650. Stanford: Stanford University Press, 1974.

14. CAMPBELL, Gwyn (Ed.). Structure of slavery in Indian Ocean Africa and Asia. London: Frank Cass, 2004.

15. CASELLI, Graziella; VALLIN, Jacques; WUNSCH, Guillaume J. Demography: analysis and synthesis. Vol. III. Amsterdam: Academic Press, 2006.

16. CHRISTOPHER, Emma. Josefa Diago and the origins of Cuba's Gangá traditions. Transition, n. 111, p. 133-44, 2013.

17. CLEALAND, Danielle $P$. The power of race in Cuba: racial ideology and black consciousness during the revolution. New York: Oxford University Press, 2017.

18. COATES, Timothy. Convicts and orphans. Forced and State-sponsored colonizers in the Portuguese empire, 1550-1755. Stanford: Stanford University Press, 2001.

19. COATES, Timothy. Convict labor in the Portuguese empire, 1740-1932: redefining the empire. Leiden: Brill, 2014.

20. CORACH, Daniel et al. Inferring Continental Ancestry of Argentineans from Autosomal, Y-Chromosomal and Mitochondrial DNA. Annals of Human Genetics, v. 74, n. 1, p. 65-76, 2010.

21. CORBITT, Duvon. A study of the Chinese in Cuba, 1847-1947. Wilmore: Ashbury College, 1971.

22. CRYSTAL, David (Ed.). The Cambridge encyclopedia of the English language. Berkeley: Cambridge University Press, 2004.

23. DEBIEN, Gabriel. Les engagés pour les Antilles, 1634-1715. Revue d'histoire des colonies, v. 38, p. 5-274, 1951.

24. DOORTMONT, Michael R. The invention of the Yorubas: regional and PanAfrican nationalism versus ethnic provincialism. In: FARIAS, P. F. de Moraes; BARBER, Karin. (Eds.). Self-assertion and brokerage: early cultural nationalism in West Africa. Birmingham: University of Birmingham, 1990, p. 101-108.

25. DUPUY, Alex. French merchant capital and slavery in Saint-Domingue. Latin American Perspectives, v. 12, n. 3, p. 77-102 1985.

26. ELTIS, David. The total product of Barbados, 1664-1701. The Journal of Economic History, v. 55, n. 2, p. 321-338, 1995.

27. ERDEl, Ezequiel. Choosing each other: exogamy in the Jewish community of Buenos Aires. Oxford: JDC International Centre for Community Development, 2014. Available at: <http://www.jdc-iccd.org/en/article/64/choosing-each-otherexogamy-in-the-jewish-community-of-buenos-aires $>$. 
28. ESTRADA-VERAS, Juvianee et al. Medical genetics and genomic medicine in the Dominican Republic. Molecular Genetics \& Genomic Medicine, v. 4, n. 3, p. 243-56, 2016.

29. FERNÁNDEZ, Francisco M.; ROTH, Jaime O. Demografía de la lengua Española. Madrid: Instituto Complutense de Estudios Internacionales, 2006.

30. FERREIRA, Roquinaldo. Cross-cultural exchange in the Atlantic World: Angola and Brazil during the era of the slave trade. New York: Cambridge University Press, 2012.

31. FRAGINALS, Manuel M.; MASÓ, José M. Guerra, migración y muerte: el ejército español en Cuba como vía migratoria. Gijón: Ediciones Júcar, 1999.

32. FREYRE, Gilberto. The masters and the slaves. Berkeley: University of California Press, 1986.

33. GATES, Henry Louis. Black in Latin America. New York: New York University Press, 2011.

34. GOMEZ-CASADO, E. et al. HLA Genes in Arabic-speaking Moroccans: close relatedness to Berbers and Iberians. Tissue Antigens, v. 3, p. 239-49, 2000.

35. GONZÁLEZ, Nancie L. S. Dollar, dove, and eagle: one hundred years of Palestinian migration to Honduras. Ann Arbor: University of Michigan Press, 1992.

36. HIDALGO, Pedro et al. Genetic admixture estimate in the Uruguayan population. International Journal of Human Genetics, v. 5, p. 217-22, 2005.

37. HODOĞLUGIL, Uğur; MAHLEY, Robert. Turkish population structure and genetic ancestry reveal relatedness among Eurasian populations. Annals of Human Genetics, v. 76, n. 2, p. 128-41, 2012.

38. HOMBURGER, Julian R. et al. Genomic insights into the ancestry and demographic history of South America. PLoS Genet, v. 11, n. 12, [online preprint], 2015.

39. HUETZ DE LEMPS, Christian. Indentured servants bound for the French Antilles in the seventeenth and eighteenth centuries. In: ALTMAN, Ida; HORN, James (Eds.), "To make America": European emigration in the early modern period. Berkeley: University of California Press, 1991, p. 172-203.

40. JORDAN, Don; WALSH, Michael. White cargo: the forgotten history of Britain's white slaves in America. New York: NYU Press, 2008.

41. KILLINGRAY, David; PHILLIPS, Howard (Eds.), The Spanish Influenza pandemic of 1918-1919: New Perspectives. London: Routledge, 2003.

42. KLEIN, Herbert S. African slavery in Latin America and the Caribbean. New York: Oxford University Press, 1986.

43. KRUIJTZER, Gijs. European migration in the Dutch sphere. In: OOSTINDIE, Gert (Ed.). Dutch colonialism, migration and cultural heritage. Leiden: KITLV Press, 2008, p. 97-154. 
44. LAGARDE, Agnieska D. de. La formación de la sociedad colonial más peculiar del Imperio español: la emigración europea a Filipinas en la primera mitad del siglo XVII. PhD Dissertation, Universidad Autónoma del Estado de Morelos, México, Facultad de Humanidades, 2008.

45. LINCOLN, W. Bruce. The conquest of a continent: Siberia and the Russians. Ithaca: Cornell University Press, 2007.

46. MCCLEARY, Kristen. Life is a cabaret? Theater and the creation of modern Argentina, 1880-1930. Book manuscript, 2015.

47. MILLER, Ivor. Voice of the leopard: African secret societies and Cuba. Jackson: University Press of Mississippi, 2009.

48. MONZOTE, Reinaldo F. From rainforest to cane field in Cuba: an environmental history since 1492. Chapel Hill: University of North Carolina Press, 2008.

49. MOOGK, Peter. Manon's fellow exiles: emigration from France to North America before 1763. In: CANNY, Nicholas (Ed.). Europeans on the move: studies on European migration, 1500-1800. New York: Oxford University Press, 1994.

50. MORGAN, Kenneth. Slavery and servitude in colonial North America. New York: NYU Press, 2001.

51. MOYA, José C. Cousins and strangers: Spanish immigrants in Buenos Aires, 1850-1930. Berkeley: University of California Press, 1998.

52. MOYA, José C. Spanish immigration in Cuba and Argentina. In: BAILY, Samuel L.; MIGUEZ, Eduardo J. (Eds.). Mass migration to modern Latin America. Wilmington: Scholarly Resources, 2003.

53. MOYA, José C. The positive side of stereotypes: Jewish anarchists in earlytwentieth-century Buenos Aires. Jewish History, v. 18, n. 1, p. 19-48, 2004.

54. MOYA, José C. Immigrants and associations: a global and historical perspective. Journal of Ethnic and Migration Studies, v. 31, n. 5, p. 833-64, 2005.

55. MOYA, José C. A Continent of immigrants: postcolonial shifts in the Western hemisphere. Hispanic American Historical Review, v. 86, n. 1, p. 1-28, 2006.

56. MOYA, José C. Immigration, development, and assimilation in the United States in a global perspective, 1850-1930. Studia Migracyijne, Warsaw, v. 35, n. 3, p. 89-104, 2009.

57. MOYA, José C. Immigration in Latin America, an online bibliography. Oxford Bibliographies, 2011. <www.oxfordbibliographies.com/view/document/obo9780199766581/obo-9780199766581-0075.xml>.

58. MOYA, José C. Migración africana y formación social en las Américas, 15002000. Revista de Indias, v. LXXII, n. 255, p. 319-45, 2012.

59. MOYA, José C. Cuba: Immigration and emigration. In: The encyclopedia of global human migration. Oxford: Wiley-Blackwell, 2013a. 
60. MOYA, José C. The Jewish experience in Argentina in a diasporic perspective. In: BRODSKY, Adriana; REIN, Raanan (Eds.). The New Jewish Argentina. Leiden: Brill, 2013b, p. 7-29.

61. MOYA, José C. América Latina y los flujos transatlánticos: una categoría histórica desde una perspectiva global. In: AZCUE, Concepción Navarro (Ed.). Vaivenes del destino: inmigrantes europeos y latinoamericanos en los espacios atlánticos. Madrid: Ediciones Polifemo, 2014, p. 21-38.

62. MOYA, José C. Canada and the Atlantic World: migration from a hemispheric perspective, 1500-1800. In: BRYCE, Benjamin; FREUND, Alexander (Eds.). Entangling migration history: borderlands and transnationalism in the United States and Canada. Gainesville: University Press of Florida, 2015a, p. 14-46.

63. MOYA, José C. A emigración azoriana e galega: unha perspectiva comparada. In: RODRÍGUEZ, Alberto Pena et al. (Eds.). Emigración e exilio dos Estados Unidos de América: experiencias de Galiciae Azores. Santiago de Compostela: Consello da Cultura Galega, $2015 b$.

64. MOYA, José C. América Latina como categoría histórica en una perspectiva global. Istor: Revista de Historia Internacional, n. 67, p. 13-59, 2017.

65. MOYA, José C.; MCKEOWN, Adam. World migration in the long twentieth century. Washington DC: American Historical Association, 2011.

66. MUNIZ, Yara N. et al. Genomic ancestry in urban Afro-Brazilians. Annals of Human Biology, v. 35, n. 1, p. 104-11, 2008.

67. MURILLO, Maria Dolores P. Cartas de emigrantes escritas desde Cuba: estudio de las mentalidades y valores en el siglo XIX. Cadiz: Universidad de Cádiz, 1999.

68. NEWLAND, Carlos. La educación elemental en Hispanoamerica: desde la independencia hasta la centralización de los sistemas educativos nacionales. The Hispanic American Historical Review, v. 71, n. 2, p. 335-364, 1991.

69. NEWSON, Linda; MINCHIN, Susie. From capture to sale: the Portuguese slave trade to Spanish America in the early seventeenth century. Leiden: Brill, 2007.

70. PIKE, Ruth. Penal servitude in early modern Spain. Madison: University of Wisconsin Press, 1983.

71. POMERANZ, Kenneth; TOPIK, Steven. The world that trade created: society, culture, and the world economy, 1400-the present. Armonk: M. E. Sharpe, 1999.

72. PUTTERMAN, Louis; WEIL, David N. Post-1500 population flows and the long-run determinants of economic growth and inequality. The Quarterly Journal of Economics, v. 125, n. 4, p. 1627-82, 2010.

73. REIN, Raanan. Fútbol, Jews, and the making of Argentina. Stanford: Stanford University Press, 2015.

74. REINHARZ, Shulamit; DELLAPERGOLA, Sergio (Eds.). Jewish intermarriage around the world. New Brunswick: Transaction Books, 2009. 
75. REIS, João. Slave rebellion in Brazil: the Muslim uprising of 1835 in Bahia. Baltimore: Johns Hopkins University Press, 1993.

76. REIS, João; KLEIN, Herbert. Slavery in Brazil. In: MOYA, José C. (Ed.). Handbook of Latin American History. New York: Oxford University Press, 2011, p. 181-211.

77. RICOURT, Milagros. Dominican racial imaginary: surveying the landscape of race and Nation in Hispaniola. New Brunswick: Rutgers University Press, 2016.

78. ROBERTS, Lois J. The Lebanese immigrants in Ecuador: a history of emerging leadership. Boulder: Westview Press, 2000.

79. SALZANO, Francisco M.; SANS, Mónica. Interethnic admixture and the evolution of Latin American populations. Genetics and Molecular Biology, v. 37, n. 1, p. 151-70, 2014.

80. SANTOS, Ricardo Ventura et al. Color, race, and genomic ancestry in Brazil. Current Anthropology, v. 50, n. 6, p. 787-819, 2009.

81. SCHWARTZ, Stuart B. Cantos e quilombos numa conspiração de escravos Hausás. In: REIS, João; GOMES, Flávio (Ed.). Liberdade por um fio: história dos quilombos no Brasil. São Paulo: Companhia das Letras, 1997, p. 373-404;

82. SCHWEGLER, Armin et al. (Eds.). The Iberian challenge: Creole languages beyond the plantation setting. Madrid: Iberoamericana, 2016.

83. SILVA, Filipa R. da. Dutch and Portuguese in Western Africa: empires, merchants and the Atlantic system, 1580-1674. Leida: Brill, 2011, p. 97-118.

84. SILVA-ZOLEZZ, Irma et al. Análisis de la diversidad genómica en las poblaciones mestizas mexicanas para desarrollar medicina genómica en México. PNAS - Proceedings of the National Academy of Sciences of the United States of America, v. 106, n. 21, 2009, 8611-6.

85. SIMMONS, Kimberly $\mathrm{E}$. Reconstructing racial identity and the African past in the Dominican Republic. Gainesville: University Press of Florida, 2011.

86. SIMONS, Gary F.; FENNIG, Charles D. (Eds.). Ethnologue: languages of the world. 2nd ed. Dallas: SIL International, 2017. Online version: <http://www. ethnologue.com $>$.

87. SLENES, Robert. Na senzala uma flor: esperanças e recordações na formação da família escrava: Brasil Sudeste, século XIX. Rio de Janeiro: Nova Fronteira, 1999.

88. SLICHER VAN BATH, Bernard $H$. The absence of white contract labor in Spanish America during the colonial period. In: EMMER, Pieter. C. (Ed.), Colonialism and migration: indenture labor before and after slavery. Dordrecht: Nijhoff, 1986, p. 19-31.

89. SOLER, Luis Díaz. Historia de la esclavitud negra en Puerto Rico. San Juan: Universidad de Puerto Rico, 2005. 
90. STEWART, Hamish M. Convict labour extraction and transportation from Britain and Ireland, 1615-1870. In: DE VITO, Christian; LICHTENSTEIN, Alex (Eds.). Global convict labour. Leiden: Brill, 2015, p. 168-200.

91. TRUZZI, Oswaldo. Patrícios: sírios e libaneses em São Paulo. São Paulo: Editora Unesp, 2008.

92. TUTINO, John. Making a new world: founding capitalism in the Bajío and Spanish North America. Durham: Duke University Press, 2011.

93. UNESCO. Progress of literacy in various countries. Paris: UNESCO, 1953.

94. VAUGHAN, Umi. Rebel dance, renegade stance: Timba music and black identity in Cuba. Ann Arbor: University of Michigan Press, 2012.

95. VERGER, Pierre. Flux et refluxe la traite des nègres entre le golfe de Bénin et Bahia de Todos os Santos du xvii au xix siècle. Paris: Mouton, 1968.

96. WAGNER, Regina. Los alemanes en Guatemala, 1828-1944. Guatemala: Editorial IDEA, 1991.

97. WATKINS, W. Scott et al. Genetic analysis of ancestry, admixture and selection in Bolivian and Totonac populations of the New World. BMC Genetics, [online] v. 13, n. 39, 2012.

98. WRIGHT, John. The Trans-Saharan slave trade: history and society of the Islamic World. London: Routledge, 2007.

99. YUN, Lisa. The coolie speaks: Chinese indentured laborers and African Slaves in Cuba. Philadelphia: Temple University Press, 2008.

Received: 09 May 2018

Accepted: 01 Aug. 2018 